\section{Ideologi Penerjemahan Dongeng Fabel dalam Buku Kumpulan Kisah Menjelang Tidur (Bedtime Favorites)}

Dyan Paramitha A. P. Mahasiswa Pascasarjana Prodi Linguistik UGM Surel: dyan.paramitha.a@mail.ugm.ac.id

\title{
INTISARI
}

Penerjemahan karya sastra anak merupakan penerjemahan yang perlu melibatkan pertimbangan tentang kondisi anak-anak yang akan menjadi target pembacanya. Hal ini sejalan dengan pendapat yang disampaikan oleh Puurtinen (1998:527) bahwa dalam menerjemahkan karya sastra anak, ketepatan penyampaian dan tingkat kesulitan terkait dengan budaya sasaran, perlu dipertimbangkan. Sehubungan dengan hal tersebut, penelitian ini membahas tentang terjemahan karya sastra anak yang difokuskan pada analisis teknik dan metode penerjemahan. Teknik dan metode diteliti dengan tujuan menemukan ideologi penerjemahan yang digunakan pada teks sasaran. Analisis tersebut dilakukan pada dua dongeng fabel pengantar tidur yang terdapat pada buku Kumpulan Kisah Menjelang Tidur yang diterjemahkan dari buku berjudul Bedtime Favorites. Hasil penelitian ini menunjukkan bahwa kedua dongeng yang dianalisis menunjukkan penggunaan ideologi yang serupa, yaitu foreinisasi. Walaupun begitu, ideologi foreinisasi yang diterapkan pada dua dongeng tersebut memiliki perbedaan pada penerapan teknik dan metode penerjemahannya.

\section{Kata Kunci: Penerjemahan; Ideologi; Karya Sastra Anak}

\section{PENDAHULUAN}

Penerjemahan karya sastra anak seringkali dijumpai di dunia literasi anak Indonesia. Berbagai jenis karya sastra anak yang berasal dari bahasa-bahasa asing seperti, Inggris, Arab, Prancis, dan lain sebagainya, diterjemahkan ke dalam bahasa Indonesia. Hal ini tentunya berkaitan dengan kebutuhan karya sastra untuk anak-anak di Indonesia. Pada satu sisi, terdapat karya sastra anak yang diterjemahkan dengan adaptasi budaya bahasa sasaran sedangkan pada sisi lain, terdapat karya sastra anak yang terjemahannya disesuaikan dengan budaya bahasa sumber. Baik terjemahan yang budayanya diadaptasi ke dalam budaya bahasa sasaran maupun terjemahan yang budaya bahasa sumbernya tetap dipertahankan, keduanya memiliki kelebihan dan kekurangan masing-masing. Penerjemah yang mempertimbangkan penerimaan budaya pembaca bahasa sasaran, dalam hal ini anak-anak, hasil terjemahannya akan memudahkan para pembaca untuk mencerna karya-karya sastra anak yang mereka baca. Di samping itu, jika penerjemah mempertahankan budaya bahasa sumber pada hasil terjemahan, pembaca akan diberi gambaran budaya teks sumber yang dapat memperkaya pengetahuan pembacanya. Namun, kedua pendekatan tersebut memungkinkan pembaca mengalami kesulitan dalam memahami alur cerita dan detil cerita dalam karya sastra anak yang diterjemahkan. Maka dari itu, perlu adanya pertimbangan-pertimbangan tertentu yang harus diambil oleh penerjemah dalam menerjemahkan karya sastra anak. Hal-hal yang berhubungan dengan adaptasi budaya dan pemertahanan budaya tersebut, berkaitan erat dengan ideologi penerjemahan yang diaplikasikan pada hasil terjemahan.

Ideologi penerjemahan karya sastra anak menjadi salah satu hal yang penting untuk dipertimbangkan. Hal ini dikarenakan anak-anak pembaca karya sastra masih dalam proses pembelajaran tentang budaya yang ada di sekitarnya. Ketika buku terjemahan yang disajikan mengandung budaya-budaya yang masih terlalu asing bagi mereka, anak-anak akan kesulitan untuk memahami konteks budaya yang mereka pelajari dari lingkungan sekitar mereka. Seperti yang dikemukakan oleh Whitelaw (2017:33-34) bahwa karya sastra anak mengandung hal kompleks di 
mana orang dewasa mempunyai kuasa untuk mengajari anak melalui dongeng-dongeng yang diceritakan. Maka dari itu, penelitian ini membahas tentang ideologi penerjemahan karya sastra anak, khususnya dongeng fabel, yang terdapat dalam buku Kumpulan Kisah Menjelang Tidur yang diterjemahkan dari buku berbahasa Inggris, berjudul Bedtime Favorites.

Buku Kumpulan Kisah Menjelang Tidur (Bedtime Favorites) dipilih karena buku tersebut berisi tentang cerita-cerita tokoh animasi Disney. Disney sendiri merupakan satu-satunya industri hiburan yang masuk ke dalam 10 besar industri dengan merek paling bernilai versi Forbes tahun 2017. Hal ini dapat dilihat dari maraknya tokoh-tokoh Disney yang ilustrasinya digunakan pada berbagai macam barang yang diproduksi untuk anak-anak. Oleh karenanya, dapat dikatakan bahwa tokoh-tokoh ilustrasi Disney dikenal oleh anak-anak Indonesia yang mana mereka sendiri atau orang tuanya mengikuti tren dunia hiburan anak. Selain itu, ilustrasi dalam buku Bedtime Favorites tidak dirubah sama sekali. Buku Kumpulan Kisah Menjelang Tidur memiliki ilustrasi yang sama persis dengan buku versi bahasa Inggrisnya. Hal tersebut menjadi menarik karena hasil terjemahan fokus pada teks dengan ilustrasi yang tidak dirubah sama sekali. Oleh karenanya, dalam penelitian kecil ini, ilustrasi pada buku Kumpulan Kisah Menjelang Tidur tidak dilibatkan dalam pembahasan.

Selanjutnya, Buku Kumpulan Kisah Menjelang Tidur (Bedtime Favorites) berisi dongeng-dogeng pengantar tidur yang jenisnya berbeda-beda. Dalam penelitian ini, hanya dongeng fabel saja yang dianalisis untuk melihat ideologi penerjemahan yang diaplikasikan pada hasil terjemahan. Secara umum, dongeng fabel merupakan cerita yang mana tokoh utamanya bukan manusia, yang penyampaiannya bertujuan untuk memberikan nilai moral (Abrar, 2016:48; Kwong, 2011:275). Lebih lanjut, kajian ini dimaksudkan untuk melihat bagaimana penerjemah menggunakan teknik, metode, dan ideologi penerjemahan untuk menerjemahkan bahasa dan gerak-gerik hewan yang digambarkan dalam dongeng fabel yang dianalisis pada penelitian ini. Penerjemahan bahasa dan gerak-gerik hewan itu sendiri memerlukan kehati-hatian ketika istilah yang terdapat pada bahasa sumber tidak terdapat pada bahasa sasaran. Hal ini dilakukan supaya anak-anak yang membaca teks sasaran mendapatkan penggambaran yang sama seperti yang digambarkan pada teks sumber. Maka dari itu, penelitian ini akan membahas tentang ideologi penerjemahan dongeng fabel dalam buku Kumpulan Kisah Menjelang Tidur yang diterjemahkan dari versi bahasa Inggris, Bedtime Favorites, melalui analisis teknik dan metode penerjemahan yang digunakan.

Analisis yang dilakukan pada kajian ini didasarkan pada 18 jenis teknik penerjemahan yang diajukan oleh Molina \& Albir (2002). I 8 jenis teknik tersebut adalah adaptasi, amplifikasi linguistik, deskripsi, generalisasi, kalke, kompensasi, kompresi linguistik, kreasi diskursif, modulasi, padanan lazim, partikularisasi, peminjaman, penambahan, penerjemahan harfiah, reduksi, substitusi, transposisi, dan variasi. Kemudian, analisis metode penerjemahan didasarkan pada 8 jenis teknik yang dikemukakan oleh Newmark ( 1988 ) yang terdiri dari penerjemahan kata-demi-kata, penerjemahan harfiah, penerjemahan setia, penerjemahan semantis, penerjemahan adaptasi, penerjemahan bebas, penerjemahan idiomatik, dan penerjemahan komunikatif. Selain itu, penelitian ini juga menggunakan teori ideologi yang disampaikan oleh Venuti (2008), yang terdiri dari dua jenis, yaitu foreinisasi dan domestikasi.

Penelitian mengenai terjemahan karya sastra anak dan ideologi penerjemahan sudah dilakukan oleh beberapa peneliti, baik di dalam maupun di luar negeri. Shafira (20l8) meneliti metode dan ideologi penerjemahan komik Les Aventures de Tintin seri L'ile Noire dan Tintin au Tibet yang diterjemahkan dari bahasa Prancis ke dalam bahasa Indonesia. Kusumayanti (2016) menganalisis respon penerjemah dalam buku cerita anak dwibahasa, Inggris dan Indonesia. Sulistyowati (20I5) mengkaji tentang prosedur permainan kata dalam novel anak berjudul Judy Moody, Girl Detective, yang diterjemahkan dari bahasa Inggris ke dalam bahasa Indonesia. Mansour (2014) meneliti strategi foreinisasi dan domestikasi istilah berkonsep budaya, dalam buku The Burglar Who Liked to Quote Kipling dari bahasa Inggris ke dalam bahasa Arab. Kemudian, Schmidt (20I3) membahas tentang strategi domestikasi dan foreinisasi dalam buku terjemahan berbahasa Krosia dengan perhatian pada perubahan diakronis yang terjadi. Namun, penelitian sebelumnya belum membahas mengenai teknik, metode, dan ideologi karya sastra anak berjenis dongeng fabel yang terdapat di dalam buku kumpulan dongeng pengantar tidur terbitan Disney dan terjemahan bahasa Indonesianya. Oleh karenanya, teknik, metode, dan ideologi penerjemahan dua dongeng fabel, dalam buku tersebut, 
yang berjudul Good Night, Thumper dan A Trusty Baby Sitter beserta terjemahannya "Selamat Malam, Thumper" dan "Pengasuh Terpercaya" diangkat pada penelitian ini.

Lebih lanjut, penelitian ini merupakan penelitian deskriptif komparatif. Penelitian ini disebut deskriptif karena fenomena yang menjadi topik pada kajian ini disampaikan dengan penjelasan yang berbentuk deskripsi. Di samping itu, penelitian ini disebut kualitatif karena kajian ini fokus pada analisis teks tanpa memberikan prediksi dan generalisasi (Creswell, 1998:15). Selanjutnya, sumber data yang digunakan pada penelitian ini adalah buku Kumpulan Kisah Menjelang Tidur yang diterbitkan oleh PT. Gramedia Pustaka Utama pada tahun 20I8. Buku tersebut merupakan hasil terjemahan dari buku Bedtime Favorites yang diterbitkan oleh Disney Press pada tahun 2016. Data pada penelitian ini merupakan kata, frasa, klausa, dan kalimat yang mengandung teknik penerjemahan dan juga paragraf yang mengandung metode penerjemahan. Jumlah data yang digunakan pada penelitian ini adalah 197 data teknik penerjemahan dan 19 data metode penerjemahan, sehingga jumlah total data yang digunakan adalah 216 data. Data tersebut berasal dari dua judul dongeng fabel bahasa Inggris beserta terjemahannya dalam bahasa Indonesia yang berjudul Good Night, Thumper (Selamat Malam, Thumper) dan A Trusty Baby Sitter (Pengasuh Terpercaya). Setelah data terkumpul, teknik penerjemahan dianalisis terlebih dahulu. Hal ini dilakukan supaya metode penerjemahan dapat dianalisis pada proses kajian di tahap selanjutnya. Setelah teknik dan metode penerjemahan dianalisis, ideologi penerjemahan yang diterapkan dapat ditemukan. Tahapan-tahapan analisis tersebut didasarkan pada kerangka teori yang telah dijabarkan sebelumnya. Ketika analisis sudah diselesaikan, kesimpulan dapat ditarik berdasarkan hasil analisis yang telah dilakukan.

\section{PEMBAHASAN}

Pada bagian pembahasan ini, penggunaan teknik, metode, dan ideologi dari masing-masing dongeng fabel yang dianalisis dijabarkan sebagai berikut.

\section{1. 'Selamat Malam, Thumper' (Good Night, Thumper)}

Dongeng 'Selamat Malam, Thumper' yang berasal dari dongeng Good Night, Thumper dianalisis teknik, metode, dan ideologinya. Berikut uraiannya.

\section{a. Teknik Penerjemahan}

\begin{tabular}{l|cc} 
Teknik Penerjemahan & Jumlah & Persentase \\
\hline Harfiah & 30 & $36,6 \%$ \\
Padanan Lazim & 14 & $17,1 \%$ \\
Kompresi Linguistik & 8 & $9,8 \%$ \\
Penambahan & 8 & $9,8 \%$ \\
Reduksi & 8 & $9,8 \%$ \\
Kompensasi & 4 & $4,9 \%$ \\
Transposisi & 4 & $4,9 \%$ \\
Modulasi & 3 & $3,6 \%$ \\
Adaptasi & 2 & $2,4 \%$ \\
Peminjaman & 1 & $1,2 \%$ \\
Amplifikasi Linguistik & - & 0 \\
Deskripsi & - & 0 \\
Generalisasi & - & 0 \\
Kalke & - & 0 \\
Kreasi Diskursif & - & 0 \\
Partikularisasi & - & 0 \\
Substitusi & - & 0 \\
Variasi & - & 0 \\
Total & 82 & $100 \%$ \\
\hline
\end{tabular}


Tabel 1. Distribusi Teknik Penerjemahan dalam dongeng fabel 'Selamat Malam, Thumper' (Good Night, Thumper)

Dari tabel di atas, dapat diketahui bahwa terdapat 10 jenis teknik yang digunakan pada terjemahan dongeng fabel 'Selamat Malam, Thumper' (Good Night, Thumper), yaitu: penerjemahan harfiah, padananan lazim, kompresi linguistik, penambahan, reduksi, kompensasi, transposisi, modulasi, adaptasi, dan peminjaman. Pertama, teknik penerjemahan harfiah digunakan sebanyak 36,6 persen pada penerjemahan dongeng fabel 'Selamat Malam, Thumper' (Good Night, Thumper). Teknik penerjemahan harfiah merupakan teknik yang digunakan untuk menerjemahkan kata-per-kata (Molina \& Albir, 2002:510). Hal ini menunjukkan bahwa terjemahan kata-per-kata digunakan secara dominan pada penerjemahan dongeng fabel tersebut. Selain itu, teknik tersebut menyebabkan hasil terjemahan terdengar tidak alamiah. Sebagai contoh: a) It's past their bedtime (GNT/23) diterjemahkan menjadi Ini sudah lewat jam tidur mereka (SMT/23), b) Maybe his chipmunk and squirrel friends would want to play (GNT/28) diterjemahkan menjadi Mungkin tupai dan bajing teman-temannya mau bermain (SMT/28), dan c) His mama was calling his name (GNT/36) diterjemahkan menjadi Mamanya memanggil namanya (SMT/36). Dari contoh-contoh di atas, dapat dilihat bahwa hasil terjemahan terasa kaku dan masih sangat terpatok dengan teks sumber.

Selanjutnya, teknik padanan lazim menempati urutan jenis teknik kedua yang digunakan secara dominan pada penerjemahan dongeng fabel 'Selamat Malam, Thumper' (Good Night, Thumper). Teknik padanan lazim diaplikasikan dengan cara menerjemahkan teks sumber sesuai dengan makna kamus atau istilah yang lazim digunakan pada bahasa sasaran (Molina \& Albir, 2002:5 I0) Teknik padanan lazim digunakan sebanyak I7,I persen pada dongeng fabel tersebut. Hal ini berarti bahwa hasil terjemahan mengandung ekspresi yang diterjemahkan sesuai dengan ekspresi yang sepadan dalam teks sasaran. Teknik penerjemahan ini digunakan untuk membuat hasil terjemahan terdengar alamiah. Contohnya: a) "Can the three ducklings come out to play?" Thumper asked (GNT/2I) diterjemahkan menjadi "Bolehkah ketiga anak itik bermain sekarang?" tanya Thumper (SMT/2I), b) Suddenly, Thumper heard a familiar voice (GNT/34) diterjemahkan menjadi Tiba-tiba, Thumper mendengar suara yang tak asing lagi (SMT/34), dan c) "Sweet dreams!" (GNT/68) diterjemahkan menjadi "Mimpi indah!" (SMT/68). Contoh-contoh di atas menunjukkan bahwa teks sumber diterjemahkan sesuai dengan istilah yang lazim digunakan pada teks sasaran. Contoh terjemahan a menggambarkan bagaimana penerjemah menyampaikan makna come out to play sebagai 'bermain' dan menambahkan 'sekarang' untuk merepresentasikan kala yang terdapat pada teks sumber. Di samping itu, contoh b) menunjukkan bahwa frasa familiar voice diterjemahkan dengan istilah yang lazim dipakai pada bahasa Indonesia sedangkan contoh c memperlihatkan bahwa ucapan sweet dream tidak diterjemahkan secara harfiah 'mimpi manis', namun diterjemahkan dengan ucapan yang lebih berterima.

Lebih lanjut, teknik yang digunakan pada terjemahan dongeng fabel tersebut adalah kompresi linguistik. Teknik ini digunakan untuk menyatukan elemen linguistik pada teks sasaran (Molina \& Albir, 2002:510). Dalam hal ini, teknik kompresi linguistik digunakan dalam penerjemahan dongeng 'Selamat Malam, Thumper' (Good Night, Thumper) untuk membuat hasil terjemahan lebih simpel, dengan tetap menyampaikan pesan yang terkandung dalam teks sumber secara utuh. Teknik tersebut digunakan sebanyak 9,8 persen. Penggunaan teknik kompresi linguistik dapat dilihat pada contoh berikut: a) Thumper said good night to his friend and bounced away (GNT/I8) diterjemahkan menjadi Thumper balas mengucapkan selamat malam dan melompat pergi, dan b) They were his best friends! (GNT/46) diterjemahkan menjadi Mereka sahabatnya! (SMT/46). Dua contoh penggunaan teknik kompresi linguistik di atas menunjukkan bahwa terjemahan pada teks sasaran dibuat lebih singkat.

Selain teknik kompresi linguistik yang digunakan sebanyak 9,8 persen, terdapat dua jenis teknik lainnya yang digunakan sebanyak 9,8 persen, yaitu teknik penambahan dan teknik reduksi. Teknik penambahan dan teknik reduksi merupakan dua teknik yang saling bertolak belakang. Teknik penambahan diaplikasikan pada teks sasaran untuk menambahkan informasi yang tidak terdapat pada teks sumber (Molina \& Albir, 2002:510). Teknik penambahan pada terjemahan 'Selamat Malam, Thumper' diterapkan untuk memperjelas informasi pada teks sasaran. 
Contohnya: a) A mother duck was tucking her baby ducklings into bed (GNT/20) diterjemahkan menjadi lbu itik sedang menidurkan ketiga anaknya (SMT/20) dan b) You can all play in the morning (GNT/24) diterjemahkan menjadi Kalian bisa bermain bersama besok pagi (SMT/24). Contoh data a menunjukkan bahwa ada penambahan keterangan numeral 'ketiga' sedangkan pada contoh data $b$ terdapat penambahan informasi 'besok'.

Di sisi lain, teknik reduksi merupakan teknik yang digunakan untuk memadatkan informasi pada teks sasaran (Molina \& Albir, 2002:5I0). Pada teks dongeng fabel tersebut, teknik reduksi digunakan untuk membuat hasil terjemahan tidak bertele-tele karena terjemahan yang disediakan sudah menjelaskan informasi yang terkandung pada teks sumber, seperti contoh berikut: a) All of the bunnies had gone to sleep for the night (GNT/4) diterjemahkan menjadi Semua kelinci sudah bersiap tidur (SMT/4) dan b) Thumper wasn't tired at all (GNT/6) diterjemahkan menjadi Thumper belum lelah (SMT/6). Kedua contoh tersebut menunjukkan bahwa terdapat informasi yang dipadatkan pada teks sasaran.

Selajutnya, terdapat dua teknik yang digunakan sebanyak 4,9 persen pada penerjemahan dongeng fabel tersebut. Kedua teknik tersebut adalah kompensasi dan transposisi. Teknik kompensasi merupakan teknik yang diterapkan untuk mengganti elemen bahasa sumber yang tidak terdapat pada bahasa sasaran, teknik ini juga dapat digunakan untuk mepertahankan efek stilistika pada teks sasaran (Molina \& Albir, 2002:510). Teknik kompensasi pada dongeng 'Selamat Malam, Thumper' diterapkan untuk menerjemahkan istilah yang padanannya tidak lazim digunakan pada bahasa sasaran, sebagai contoh: Thumper went outside to wash his paws, ears, and feet before bed (GNT/48a) diterjemahkan menjadi Thumper ke luar untuk mencuci tangan, telinga, dan kakinya sebelum tidur (SMT/48a). Pada contoh ini, paws diterjemahkan menjadi 'tangan' karena bahasa sasaran tidak memiliki istilah khusus untuk kaki/tangan kucing seperti bahasa sumber yang memiliki istilah paw.

Selain itu, teknik transposisi diterapkan untuk mengubah kategori gramatikal pada teks sasaran (Molina \& Albir, 2002:5II). Pada terjemahan dongeng fabel tersebut, teknik transposisi digunakan untuk menyesuaikan hasil terjemahan dengan elemen gramatikal teks sasaran. Hal tersebut dapat dilihat pada contoh berikut: I have to get ready for bed (GNT/I2)_diterjemahkan menjadi Aku harus bersiap tidur (SMT/I2). Contoh tersebut menunjukkan bahwa terjadi perubahan kategori gramatikal yang awalnya nomina, bed, menjadi verba, 'tidur'.

Teknik yang akan dibahas selanjutnya adalah teknik modulasi. Teknik modulasi diterapkan untuk mengganti sudut pandang, titik fokus, ataupun kategori kognitif pada teks sasaran yang dikaitkan dengan konten yang dibangun pada teks sumber (Molina \& Albir, 2002:5I0). Teknik tersebut digunakan sebanyak 3,6 persen pada terjemahan dongeng Good Night, Thumper. Berkaitan dengan penggunaan teknik modulasi, teks sasaran 'Selamat Malam, Thumper' mengandung teknik modulasi yang dimanfaatkan untuk mengganti kalimat aktif pada teks sumber menjadi kalimat pasif pada teks sasaran. Hal ini dipengaruhi oleh kebiasaan penggunaan kalimat pasif pada bahasa Indonesia, sedangkan pada bahasa Inggris, kalimat aktif lebih banyak digunakan. Contoh dari penggunaan teknik modulasi adalah He perked up his long ears (GNT/35a) yang diterjemahkan menjadi Kuping panjangnya terangkat (SMT/35a). Pada teks sumber, 'he' difokuskan sebagai yang mengangkat telinga. Namun, pada teks sasaran, fokusnya berubah menjadi 'kuping'. Hal ini dilakukan karena pada bahasa sasaran, terjemahan 'ia mengangkat telinga panjangnya' terdengar tidak alamiah. Maka dari itu, penerjemah mengganti fokus pada hasil terjemahannya.

Selanjutnya, teknik adaptasi digunakan sebanyak 2,4 persen. Teknik adaptasi diterapkan untuk mengganti elemen budaya bahasa sumber menjadi elemen budaya bahasa sasaran (Molina \& Albir, 2002:509). Teknik ini digunakan untuk memudahkan pembaca memahami elemen budaya tersebut dan membuat hasil terjemahan lebih condong pada budaya bahasa sasaran. Pada terjemahan dongeng 'Selamat Malam, Thumper', teknik adaptasi digunakan mengganti elemen budaya yang terdapat pada teks sumber, Good Night, Thumper, dengan elemen budaya bahasa Indonesia, sebagai contoh: Do you want to play hide-and-go-seek? (GNT/9) diterjemahkan menjadi Kau mau main petak umpet? (SMT/9). Contoh data teknik adaptasi di atas menunjukkan bahwa hide-and-go-seek diadaptasi menjadi permainan tradisional Indonesia sehingga anak-anak 
yang membaca terjemahannya dapat membayangkan apa yang dimaksud dengan 'petak umpet' pada teks sasaran.

Terakhir, jenis teknik yang mempunyai persentase paling sedikit diantara sembilan jenis teknik lainnya adalah peminjaman. Teknik peminjaman merupakan teknik yang digunakan untuk mengambil istilah pada teks sumber dan meletakkannya pada teks sasaran secara langsung (murni) ataupun disesuaikan dengan ejaan yang berlaku pada teks sasaran (naturalisasi) (Molina \& Albir, 2002:5I0). Teknik peminjaman ini digunakan pada teks terjemahan 'Selamat Malam, Thumper' untuk menerjemahkan nama tokoh yang terdapat dalam dongeng itu, berikut penggunaan teknik peminjaman pada dongeng tersebut, Good night, Thumper (GNT/16) yang diterjemahkan menjadi Selamat malam, Thumper (SMT//6).

\section{b. Metode Penerjemahan}

\begin{tabular}{l|cc}
\multicolumn{1}{c}{ Metode Penerjemahan } & Jumlah & Persentase \\
\hline Penerjemahan Setia & 8 & $88,9 \%$ \\
\hline Penerjemahan Semantis & 1 & $11,1 \%$ \\
\hline Penerjemahan Adaptasi & - & 0 \\
\hline Penerjemahan Bebas & - & 0 \\
Penerjemahan Harfiah & - & 0 \\
Penerjemahan Idiomatik & - & 0 \\
Penerjemahan Kata-demi-Kata & - & 0 \\
Penerjemahan Komunikatif & - & $100 \%$ \\
\hline Total & 9 & 0
\end{tabular}

Tabel 2. Distribusi Metode Penerjemahan dalam dongeng fabel 'Selamat Malam, Thumper' (Good Night, Thumper)

Terdapat dua jenis metode penerjemahan yang diaplikasikan pada teks terjemahan 'Selamat Malam, Thumper'. Dua jenis metode tersebut adalah penerjemahan setia dan penerjemahan semantis, yang masing-masing digunakan sebanyak 88,9 persen dan II,I persen. Dari analisis ini, dapat dilihat bahwa metode yang secara dominan digunakan adalah metode penerjemahan setia. Metode penerjemahan setia merupakan metode yang mana terjemahannya mengandung makna yang sepadan dengan teks sumber. Namun, struktur gramatikal pada teks sasaran masih mengikuti teks sumber (Newmark, 1988:46). Hal ini membuat pesan dapat tersampaikan namun strukturnya terlihat kaku. Di sisi lain, terdapat metode semantis yang digunakan pada terjemahan tersebut. Metode penerjemahan semantis muncul karena terdapat penggunaan teknik yang lebih condong pada bahasa sasaran. Metode penerjemahan tersebut digunakan pada satu paragraf. Namun, metode tersebut tidak digunakan secara signifikan sehingga hasil terjemahan lebih dipengaruhi oleh penggunaan metode penerjemahan setia.

\section{c. Ideologi Penerjemahan}

Dari analisis teknik dan metode penerjemahan di atas, dapat dikatakan bahwa dongeng fabel 'Selamat Malam, Thumper' (Good Night, Thumper) lebih condong pada bahasa sumber. Hal ini dikuatkan dengan penggunaan teknik penerjemahan harfiah dan metode penerjemahan setia yang secara dominan digunakan dalam teks sasaran. Maka dari itu, dapat disimpulkan bahwa ideologi yang diterapkan pada terjemahan dongeng tersebut adalah foreinisasi. Ideologi foreinisasi merupakan ideologi yang mana aspek-aspek budaya teks sumber lebih ditonjolkan pada teks sasaran (Venuti, 2008:19-20). Hal ini menunjukkan bahwa teks terjemahan 'Selamat Malam, Thumper' lebih condong pada budaya yang dibangun pada teks sumber dibanding dengan penyesuaian dalam teks sasaran. 


\section{2. 'Pengasuh Terpercaya' (A Trusty Baby Sitter)}

Pada bagian ini, penggunaan teknik, metode, dan ideologi penerjemahan dalam dongeng 'Pengasuh Terpercaya' (A Trusty Baby Sitter) akan dibahas.

\section{a. Teknik Penerjemahan}

\begin{tabular}{l|cc} 
Teknik Penerjemahan & Jumlah & Persentase \\
\hline Padanan Lazim & 33 & $28,7 \%$ \\
Harfiah & 20 & $17,4 \%$ \\
Penambahan & 17 & $14,8 \%$ \\
\hline Peminjaman & 12 & $10,4 \%$ \\
\hline Reduksi & 10 & $8,7 \%$ \\
\hline Variasi & 7 & $6,1 \%$ \\
\hline Kompresi Linguistik & 5 & $4,3 \%$ \\
\hline Modulasi & 4 & $3,5 \%$ \\
\hline Transposisi & 4 & $3,5 \%$ \\
Generalisasi & 3 & $2,6 \%$ \\
\hline Adaptasi & - & 0 \\
\hline Amplifikasi Linguistik & - & 0 \\
Deskripsi & - & 0 \\
\hline Kalke & - & 0 \\
\hline Kompensasi & - & 0 \\
\hline Kreasi Diskursif & - & 0 \\
\hline Partikularisasi & - & 0 \\
\hline Substitusi & - & 0 \\
\hline Total & 115 & $100 \%$ \\
\hline
\end{tabular}

Tabel 3. Distribusi Teknik Penerjemahan dalam dongeng 'Pengasuh Terpercaya' (A Trusty Baby Sitter)

Pada teks 'Pengasuh Terpercaya' (A Trusty Baby Sitter), terdapat 10 jenis teknik yang digunakan. Pertama, teknik yang digunakan secara dominan adalah padanan lazim. Teknik tersebut digunakan sebanyak 28,7 persen. Teknik ini diterapkan untuk membuat terjemahan lebih alamiah dan mudah dipahami oleh pembaca teks sasaran, seperti yang dapat dilihat pada contoh berikut: a) Oh don't you worry, little Lady (TBS/22) diterjemahkan menjadi Oh, tak perlu khawatir, Lady kecil (PT/22) (b) Now then...where was I...? (TBS/26) diterjemahkan menjadi Nah...sampai mana tadi? (PT/26), dan c) I don't know why Lady went on so (TBS/4I) diterjemahkan menjadi Entah mengapa Lady begitu cemas (PT/4I). Ungkapan 'tak perlu khawatir' pada contoh a, 'sampai mana tadi' pada contoh b, dan 'begitu cemas' pada contoh c, menunjukkan adanya penyesuaian terjemahan dengan istilah yang lazim digunakan pada teks sasaran.

Kedua, teknik penerjemahan harfiah digunakan sebanyak 17,4 persen dalam penerjemahan 'Pengasuh Terpercaya' (A Trusty Baby Sitter). Teknik ini digunakan untuk menerjemahkan sebagian teks sumber ke dalam teks sasaran secara harfiah, sebagaimana dapat dilihat pada contoh: a) Don't let him give you any trouble (TBS/I6) diterjemahkan menjadi Jangan biarkan dia menimbulkan masalah bagimu (PT//6), b) But that had never stopped him before (TBS/52) diterjemahkan menjadi Tapi itu tak pernah menghentikannya sebelum ini (PT/52), dan c) as he and Lady stepped through the door (TBS/8I) diterjemahkan menjadi sembari melalui pintu bersama Lady (PT/8I). Hasil terjemahan pada contoh-contoh di atas masih mengikuti struktur bahasa yang digunakan pada teks sumber. Hal ini membuat terjemahannya terlihat dipaksakan karena tidak disesuaikan dengan struktur bahasa sasaran.

Ketiga, teknik penambahan memiliki porsi sebanyak 14,8 persen dalam penerjemahan 'Pengasuh Terpercaya' (A Trusty Baby Sitter). Teknik penambahan, pada kasus ini, digunakan 
untuk memberikan informasi yang lebih jelas dengan tujuan memperjelas konteks, seperti contoh berikut: a) eyeing the holes dug all over the yard (TBS/68) diterjemahkan menjadi mengamati lubang-lubang yang digali di berbagai titik halaman (PT/68) dan b) Lady pointed to the puppies' basket (TBS/93) diterjemahkan menjadi Lady menunjuk anak-anaknya dalam keranjang (PT/93). Contoh a memperlihatkan bahwa terjadi penambahan pada teks sasaran, di mana pada teks sumber tidak ada informasi mengenai 'berbagai titik' sedangkan contoh b menunjukkan bahwa adanya keterangan tambahan bahwa yang ada di dalam keranjang adalah 'anak-anaknya'.

Keempat, teknik peminjaman digunakan untuk menerjemahkan istilah yang terdapat dalam teks sumber dengan istilah yang sama dalam teks sasaran. Pada teks yang dianalisis ini, istilah yang dipindahkan dari teks sumber ke dalam teks sasaran tanpa ada perubahan adalah nama tokohtokoh dan nama/merek tertentu yang diceritakan di dalam dongeng fabel 'Pengasuh Terpercaya' (A Trusty Baby Sitter), contohnya: a) jim Dear's newspaper was in tatters (TBS/63) diterjemahkan menjadi Koram Jim Dear tercabik-cabik (PT/63) dan b) Uncle Trusty! (TBS/I2) diterjemahkan menjadi Paman Trusty! (PTI2).

Kelima, teknik reduksi digunakan sebanyak 8,7 persen pada penerjemahan A Trusty Baby Sitter. Teknik tersebut diterapkan untuk mempersingkat informasi yang sudah jelas, supaya informasinya padat dan tidak ada informasi yang mubazir. Contoh penggunaan teknik reduksi dapat dilihat pada contoh berikut: a) You're our babysitter? (TBS/I4) diterjemahkan menjadi Kau pengasuh kami? (PT//4) dan b) One bedtime story and then it's straight to bed (TBS/2I) diterjemahkan menjadi Satu dongeng dan setelahnya langsung tidur (PT/2I). Contoh a menunjukkan ada pemadatan informasi dari 'pengasuh bayi/anak', menjadi 'pengasuh' sedangkan contoh b menunjukkan bahwa keterangan 'pengantar tidur' dihilangkan menjadi 'dongeng' saja alih-alih 'dongeng pengantar tidur'.

Keenam, teknik variasi digunakan sebanyak 6,1 persen pada teks kedua yang dianalisis pada penelitian ini. Teknik variasi merupakan teknik yang digunakan untuk mengganti elemen linguistik atau paralinguistik (intonasi atau gerak isyarat) yang memengaruhi aspek variasi linguistik, seperti mengganti nada tekstual, gaya (style), dialek sosial, dan dialek geografis (Molina \& Albir, 2002:5II). Dalam hal ini, penerjemah 'Pengasuh Terpercaya' (A Trusty Baby Sitter) menggunakan teknik variasi untuk mengganti gaya bahasa yang dituliskan pada teks sasaran. Contoh teknik variasi yang diaplikasikan pada teks terjemahan tersebut adalah a) Would you, Scamp? (TBS/I8) diterjemahkan menjadi Ya kan, Scamp? (PT/I8) dan b) How did it go? (TBS/82) diterjemahkan menjadi Bagaimana, lancar? (PT/82). Dua contoh tersebut, memperlihatkan bahwa terjadi penerjemahan dengan gaya bahasa informal pada teks sasaran.

Ketujuh, teknik kompresi linguistik menduduki urutan penggunaan teknik selanjutnya, setelah teknik variasi. Teknik ini digunakan sebanyak 4,3 persen. Teknik ini digunakan penerjemah 'Pengasuh Terpercaya' (A Trusty Baby Sitter) untuk memadatkan elemen linguistik pada teks sasaran. Hal ini dilakukan untuk menyampaikan informasi yang sama dengan teks sumber. Namun, informasi tersebut disampaikan dengan jumlah kata yang lebih sedikit. Berikut contoh penggunaan kompresi linguistik pada teks tersebut: Uncle Trusty shook his head (TBS/33) diterjemahkan menjadi Paman Trusty menggeleng (PT/33).

Kedelapan, teknik modulasi digunakan sebanyak 3,5 persen dari seluruh penggunaan teknik penerjemahan pada dongeng 'Pengasuh Terpercaya' (A Trusty Baby Sitter). Teknik ini diterapkan untuk mengganti peletakan subjek, objek, dan sudut pandang pada teks sasaran. Hal ini dilakukan untuk membuat hasil terjemahan lebih mudah diterima oleh pembaca karena hasil terjemahannya didasarkan pada konvensi susunan kalimat bahasa Indonesia, seperti contoh berikut ini: If my grandpappy taught me anything, it's how to put a dog to bed! (TBS/23) yang diterjemahkan menjadi Salah satu hal yang diajarkan kakekku dengan baik adalah cara menidurkan anjing! (PT/23). Contoh ini menunjukkan bahwa perubahan sudut pandang dilakukan untuk menghindari hasil terjemahan menjadi tidak alamiah. Maka dari itu, sudut pandang pada teks sumber diganti oleh penerjemah ketika menerjemahkan klausa pada contoh data tersebut.

Kesembilan, terdapat teknik lainnya yang digunakan sebanyak 3,5 persen, yaitu: teknik transposisi. Penerapan teknik transposisi ini ditujukan untuk mengganti kategori gramatikal supaya hasil terjemahan sesuai dengan struktur bahasa Indonesia, seperti yang dapat dilihat 
pada contoh: as if a storm had just blown through it (TBS/55) yang diterjemahkan menjadi seolah baru dihantam badai! (PT/55). Pada contoh data transposisi di atas, terjadi perubahan kategori gramatikal dari kalimat aktif menjadi klausa pasif.

Terakhir, jenis teknik yang paling sedikit digunakan pada penerjemahan A Trusty Baby Sitter adalah generalisasi. Penggunaan teknik generalisasi ini dimanfaatkan untuk menerjemahkan suatu istilah dengan istilah yang memiliki arti lebih luas atau lebih netral Molina \& Albir, 2002:5 I0). Pada dongeng fabel tersebut, teknik ini digunakan seperti contoh: Scamp wasn't there anymore, but he had left behind a trail of floury paw prints (TBS/60) yang diterjemahkan menjadi Scamp sudah tak lagi di situ, tapi ia meninggalkan jejak bertepung (PT/60). Contoh ini menunjukkan bahwa istilah paw prints diterjemahkan dengan istilah yang maknanya lebih luas, yaitu 'jejak'.

\section{b. Metode Penerjemahan}

\begin{tabular}{l|cc} 
Metode Penerjemahan & Jumlah & Persentase \\
\hline Penerjemahan Semantis & 7 & $70 \%$ \\
Penerjemahan Setia & 2 & $20 \%$ \\
Penerjemahan Komunikatif & 1 & $10 \%$ \\
Penerjemahan Adaptasi & - & 0 \\
Penerjemahan Bebas & - & 0 \\
Penerjemahan Harfiah & - & 0 \\
Penerjemahan Idiomatik & - & 0 \\
Penerjemahan Kata-demi-Kata & - & 0 \\
Total & 10 & $100 \%$
\end{tabular}

Tabel 4. Distribusi Metode Penerjemahan dalam dongeng fabel 'Pengasuh Terpercaya' (A Trusty Baby Sitter)

Terdapat tiga jenis metode penerjemahan yang digunakan pada penerjemahan 'Pengasuh Terpercaya' (A Trusty Baby Sitter). Ketiga metode tersebut adalah penerjemahan semantis, setia, dan bebas, yang masing masing telah diurutkan dari penggunaan yang paling dominan. Metode penerjemahan semantis digunakan untuk menerjemahkan teks yang dekat dengan teks sumber dari sisi semantik dengan struktur gramatikal yang disesuaikan dengan struktur bahasa sasaran (Newmark, 1988:46). Metode ini digunakan paling dominan pada penerjemahan dongeng tersebut, yaitu 70 persen. Maka, dapat dikatakan bahwa pendekatan yang diaplikasikan pada terjemahan dongeng fabel itu merupakan pendekatan secara semantis. Di sisi lain, terdapat metode setia yang diterapkan pada penerjemahan dongeng tersebut, sebanyak $20 \%$. Hal ini menunjukkan bahwa masih ada terjemahan pada teks sasaran yang masih condong pada struktur teks sumber. Hal ini pun dapat dilihat dari adanya penggunaan teknik penerjemahan harfiah pada penerjemahan dongeng tersebut. Selain itu, terdapat satu paragraf yang menggunakan metode penerjemahan komunikatif. Metode penerjemahan komunikatif mengacu pada penerjemahan yang dapat diterima secara kontekstual pada teks sasaran, yang dapat dilihat dari konten informasi dan kelaziman hasil terjemahannya (Newmark, 1988:47). Paragraf yang mengandung metode penerjemahan komunikatif tersebut terletak pada bagian dongeng paling akhir. Oleh karenanya, walaupun metode ini hanya digunakan sebanyak 10 persen, hasil terjemahan di bagian akhir ini menjadikan akhir ceritanya lebih berterima secara kontekstual.

\section{c. Ideologi Penerjemahan}

Dari penjabaran analisis teknik dan metode penerjemahan di atas, ideologi dari teks terjemahan A Trusty Baby Sitter yang berjudul 'Pengasuh Terpercaya' dapat dirumuskan. Tiga teknik penerjemahan yang paling dominan digunakan adalah padanan lazim, penerjemahan harfiah, dan penambahan. Kemudian, metode penerjemahan yang dominan digunakan adalah penerjemahan semantik. Hal tersebut menunjukkan bahwa, walaupun teknik yang paling dominan digunakan adalah padanan lazim, namun teknik tersebut tersebar pada seluruh bagian cerita, di mana 
teknik harfiah juga digunakan. Hal tersebut menyebabkan metode semantis menjadi dominan. Maka dari itu, dapat dikatakan bahwa ideologi dari 'Pengasuh Terpercaya' (A Trusty Baby Sitter) lebih condong kepada bahasa sumber, yaitu foreinisasi.

\section{KESIMPULAN}

Berkaitan dengan dongeng fabel yang diterjemahkan, penerjemah 'Selamat Malam, Thumper' (Good Night, Thumper) menerjemahkan istilah-istilah yang berkaitan dengan kehidupan hewan sesuai dengan teks sumbernya. Hal ini dapat dilihat dari penggunaan teknik dan metode penerjemahannya. Teknik yang paling dominan digunakan adalah penerjemahan harfiah dan metode yang dominan digunakan adalah penerjemahan setia. Hasil analisis ini menunjukkan bahwa teks sasaran lebih condong pada teks sumber sehingga ideologinya dapat digolongkan sebagai foreinisasi. Di samping itu, penerjemah 'Pengasuh Terpercaya' (A Trusty Baby Sitter) menerjemahkan istilah yang menggambarkan kebiasaan hewan dengan memfokuskan penerjemahan dari sisi semantis. Hal ini dapat dilihat dari analisis terjemahan yang dihasilkan, di mana teknik yang mendominasi adalah padanan lazim dan metode yang mendominasi adalah penerjemahan semantis. Maka dari itu, cerita kedua yang di analisis ini juga mengandung ideologi penerjemahan foreinisasi. Akhirnya, dapat disimpulkan bahwa kedua dongeng fabel yang dianalisis memiliki ideologi yang sama. Namun, tingkat kecondongannya pada teks sumber berbeda. Dongeng 'Selamat Malam, Thumper' dapat dikatakan lebih condong pada teks sumber jika dibandingkan dengan dongeng 'Pengasuh Terpercaya'. Hal ini dikarenakan analisis teknik dan metodenya menunjukkan hasil yang sedikit berbeda. Bagaimanapun, penerjemahan karya sastra anak memerlukan kehati-hatian perihal keberterimaan struktur dan konten teks sasaran, seperti halnya yang disampaikan oleh Oittinen (2000:63) bahwa penerjemahan karya sastra anak seharusnya melibatkan pertimbangan dalam hal bagaimana anak akan menerima pesan dengan baik dan pertimbangan dalam hal pemertahan nilai estetika yang terdapat di dalamnya. Namun, pada dua dongeng yang dianalisis, hanya konten yang benar benar diperhatikan sedangkan struktur bahasa pada teks sasaran sebagian diabaikan. Hal tersebut kemudian menyebabkan konten dalam teks sumber diterjemahkan dengan penyampaian yang kurang alamiah dalam teks sasaran, ditilik dari analisis yang telah dilakukan dan dijabarkan di atas.

\section{DAFTAR PUSTAKA}

Abrar, Mukhlash. 2016. "Learning from Fables: Moral Values in Three Selected English Stories". Dinamika Ilmu, Vol. 16, No. I, Hal 47-58.

Creswell, John W. 1998. Qualitative Inquiry and Research Design: Choosing among Five Tradition. London: Sage Publications.

Kusumayanti, Dina Dyah. 2016. Respon Penerjemah dalam Buku Sastra Anak Berbentuk Buku Cerita Bergambar Berlabel 'Bilingual' Terbitan 'Erlangga For Kids'. (Disertasi Fakultas Ilmu Budaya Universitas Gadjah Mada). Yogyakarta. Tidak diterbitkan.

Kwong, Oi Yee. 20II. "Annotating The Structure and Semantics of Fables". 25th Pacific Asia Conference on Language, Information and Computation, Hal 275-282.

Mansour, Mariam Hassan. 20I4. "Domestication and Foreignization in Translating Culture-Specific References of an English Text Into Arabic". International Journal of English Language \& Translation Studies, Vol. 2, No. 2, Hal 23-36.

Molina, Lucia. \& Albir, Amparo Hurtado. 2002. "Translation Techniques Revisited: A Dynamic and Functionalist Approach”. Meta: Translators' Journal, Vol. 47, No. 4, Hal. 498-5/2. doi:10.7202/008033ar.

Newmark, Peter. 1988. A Textbook of Translation. New York: Prentice Hall International.

Oittinen, Riitta. 2000. Translating for Children. New York \& London: Garland Publishing. 
Puurtinen, Tiina. 1998. "Syntax, Readability and Ideology in Children's Literature". Meta: Translators' Journal, Vol. XLIII, No. 4, Hal. 524-533.

Shafira, Floriberrta Novia Dinda. 20 I8. Ideologi Penerjemahan Komik Les Aventures de Tintin Seri L'lle Noire dan Tintin au Tibet. (Skripsi Fakultas Ilmu Budaya Universitas Gadjah Mada). Yogyakarta. Tidak diterbitkan.

Schmidt, Goran. 2013. "Foreignization and Domestication in The Croatian Translations of Oscar Wilde's The Picture of Dorian Gray". Jezikoslovlje, Vol. I4, No. 2-3, Hal. 537-548.

Sulistyowati, Indah. 2015. "Menerjemahkan Permainan Bahasa dalam Novel Anak Judy Moody, Girl Detective". RETORIKA: Jurnal Ilmu Bahasa, Vol. I, No. 2, Hal. 220-232. doi: 10.22225/jr.I.I.I19.220-232.

Venuti, Lawrence. 2008. The Translator's Invisibility: A History of Translation (2nd ed.). London \& New York: Routledge.

Whitelaw, Jessica. 2017. "Beyond The Bedtime Story: In Search of Epistemic Possibilities and The Innovative Potential of Disquieting Picturebooks". Bookbird: A Journal of International Children's Literature, Vol. 55, No. I, Hal. 33-4I. doi: https://doi.org/I0.I353/bkb.20I7.0004. 